УДК $81 ' 25 ’ 373$

\author{
N. Shalova \\ O. Zarivna
}

\title{
LEXICAL MEANS AND TECHNIQUES OF ACHIEVING THE TRANSLATION EQUIVALENCE OF COMPOUND TERMS IN THE FIELD OF MECHANICAL ENGINEERING AND INFORMATION TECHNOLOGY
}

This article is devoted to the study of lexical means and techniques of achieving the translation equivalence of compound terms in the field of mechanical engineering and information technology. The paper provides a comprehensive analysis of the features of achieving equivalence in the translation of terminological phrases and the nature of the means and techniques of translation of compound terms. Lexical-semantic and lexicalgrammatical techniques of translation of compound terms are determined.

Key words: compound terms, calquing, explication, source language, target language, semantic features.

\section{DOI 10.34079/2226-3055-2019-12-21-218-224}

Introduction. Nowadays, translation has information and communication functions, and therefore translation is a means of providing information and communication between people who speak different languages. The modern period of language development is characterized by a significant quantitative increase in terms in various spheres of science and technology, their active penetration into common language, the process of its intellectualization, and the replenishment of the vocabulary with new units. Therefore, it can be argued that, problems of studying the peculiarities of the functioning terms in the process of scientific and technical translation are becoming increasingly relevant with the rapid development of scientific and technical information.

The topicality of the research is due to the fact that in recent decades the interest of linguists and specialists of various fields of science and technology to the problems of branch terminology has sharply increased, that is explained by the growing stream of scientific and technical information, processes of integration of sciences, strengthening processes of term formation.

The object of the study is the compound terms of engineering and information technology.

The subject of the study are the lexical means and techniques of achieving the equivalence of translation of compound terms in the field of engineering and IT which determines the purpose of our study - to consider the translation aspect of the compound terms of engineering and information technology and the features of techniques and means of achieving the equivalence of their translation.

Achievement of the goal has determined the following tasks to be solved:

- to describe the features of achieving equivalence and adequacy in translating compound terms;

- to identify means of achieving equivalence and adequacy in translating compound terms;

- to reveal the nature of lexical techniques of translation of compound terms;

- to define lexical-semantic and lexical-grammatical methods of translation of compound terms. 
Analysis of recent research and publications. The modern period of language development is characterized by a significant quantitative increase of terms in various spheres of science and technology, their active penetration into common language, the process of its intellectualization, and the replenishment of the vocabulary with new units.

A. L. Pumpyansky's study gives grounds to argue that the vocabulary of scientific and technical literature is characterized by the use of a large number of scientific and technical terms, i.e. words or phrases denoting scientific or technical concepts [7, p. 203].

One cannot disagree with A. V. Fedorov's view that the main condition for the correct translation of scientific and technical terms, i.e. choosing the right word from those that serve to convey the term of the concept in its various meanings, is an understanding of what the text deals with the language, knowledge of the phenomena of reality and their names. That is, the translator must be familiar with the relevant field of science or technology and be aware of special terminology [10, p. 218].

We agree with V. V. Akulenko's opinion that special attention in translating scientific and technical terms should be given to the so-called «false friends» of the translator, i.e. lexical units, which coincide in external and even in internal form, but cause false associations, due to the presence of another meaning, the possibility of semantic variation of the linguistic unit [1, p. 371].

E. F. Skorohodko emphasizes in his research that a very important feature of the translation of scientific and technical literature is that the interpreter often has to create equivalent Ukrainian terms for the expression of new concepts [9, p. 92].

Therefore, the need to disclose the meaning of many foreign terms and find equivalents to them independently in the native language is a peculiarity of scientific and technical literature translation.

Review of the main material. Features of achieving equivalence and adequacy in translating compound terms. The basic requirement for the translation of English terms is the complete preservation of their semantic content. The Ukrainian equivalent, functioning in a particular professional language, is also a term, and, therefore, must correspond to the basic characteristics of the term which include: lack of synonymy in one area, limitation of ambiguity, accuracy and completeness of the term, lack of expressiveness, euphonium, optimum level of motivation of terms, which is the act of displaying one or many features of objects in its name by means of language.

It is known that a large number of terms expresses the same concepts or phenomena of reality. There are many synonymous terms, polysemantic terms, terms-neologisms that do not have translation equivalents, and homonymous terms. Polysemantic terms can be both highly specialized terms and commonly used, which can have two or more meanings, even within the same terminology. For example: agreement - contract; currency - monetary unit; customer-buyer, etc [11, p. 368].

The growth of the number of internationalisms in the modern language of science and technology indicates the tendencies of international co-operation, the integration in many industries in order to improve the efficiency of professional communication and exchange of experience, for example: satellite, management, etc [11, p. 369].

We can distinguish the main parameters in the process of translation of terminological vocabulary not only by the choice of an adequate version of the content of the source text, but also the background knowledge, logic, context, ability to abstract concepts when choosing a synonym.

Thus, the translation of the English terminology group is made from the right to the left. The translation of simple terms that are part of the group should be adequate and consistent with the meaning accepted by the experts of the industry. 
A number of grammatical features can be identified in English scientific and technical materials. The same syntactic structures and morphological forms are used in the scientific and technical language as well as in other functional styles. However, a number of grammatical phenomena are noted in this style more often than in others, some phenomena, on the contrary, are rare in it, others are used only with the typical lexical «filling» $[4$, p. 56].

Therefore, translation of the term-phrase is possible only by a detailed semantic analysis of the individual elements, taking into account the content of the original text, determine the logical connection between these elements. To find meaning, you should refer to the context and additional literature in the source language and you can search the Ukrainian equivalent in dictionaries and additional literature in the target language.

Means of achieving equivalence and adequacy in translating compound terms. Among the basic means of translation of compound terms in the scientific and technical literature A. A. Weise distinguishes the following things: semantic development, concretization, generalization, introduction and omission of words, antonymic translation and paraphrase [2, p. 87].

The semantic development means is used when the dictionary equivalent of a word is out of the context. For example, a commonly used word in the scientific and technical literature «background» has several meanings in the dictionary: background, scene, prerequisite, foundation, preparation, education, qualification, questionnaire, origin. Having studied the vocabulary of the proposed variants and comparing them with the English dictionary of synonyms and the explanatory dictionary, logically developing the meaning, we have the following translation options: source material/information, general information about anything.

The need for additional words or omissions is often dictated by language norms. Antonymic translation is used only in the case of stylistic differences. From the point of view of linguistic peculiarities, the translator is obliged to use different substitutions of individual words, phrases, parts of the sentence and transformation of the whole sentence, translating from English into Ukrainian, in order to express the content of the translated text in the target language [5, p. 92].

V. D. Tabanakova proposes to develop an adequate and standardized algorithm for translating computer terms. This algorithm is called the «translation model» in the translation literature [6, p. 45]. V. N. Kommisarov developed a meaning of the term «translational model». He thinks, it is «a conditional description of a series of mental operations that, when performed, the translator can translate all or part of the original text» [5, p. 47].

The main ways of translating the terms according to E. M. Yenikieva is transliteration / transcription, transcoding, calculating, as well as descriptive and equivalent translation. Using transliteration / transcription we can translate the following English terms: operator, monitor, server, printer, computer, interface. Terms such as profile, matrix, domain, card are translated by adapted transcoding [3, p. 56].

Lexical techniques of translation of compound terms. V. N. Komisarov notes that transliteration (transcription) is used mainly for the translation of individual words-terms, and the translation of terminological phrases is carried out by means of calquing and explication. Calquing is a means of translating the lexical unit of the original one by replacing its constituent parts (morphemes or words) with their lexical correspondences in the target language [5, p. 173].

T. A. Kazakova defines calquing as the reproduction of a word or phrase that is not a sound but a combinatorial composition when the components of a word (morphemes) or phrases (tokens) are translated by the corresponding elements of the target language. 
Calquing as a means of translation served as a basis for a large number of borrowings in intercultural communication in cases where transliteration was unacceptable for aesthetic, semantic or other reasons [4, p. 89].

Having carried out the analysis of calculations, O. O. Selivanova distinguishes word-formation, semantic, word-forming syntactic and syntactic calquing and emphasizes that calquing is one of the processes of replenishment of the lexical composition of language [8, p. 199].

Thus, it should be emphasized that calquing is appropriate for the translation of terminological phrases when the constituent elements of these phrases have already occupied a certain place in the terminological system of the target language and are accessible to specialists.

Lexical-semantic and lexical-grammatical techniques of translation of compound terms. Such methods of translation of words and phrases as transliteration (transcription), calquing are applied mainly to the linguistic units of stable or universal meanings, which are independent of any context having the same or similar form and content both in the source and target language. It happens differently with linguistic units that can express different meanings depending on context, situation and implied sense: such units require special techniques for translation. These include: narrowing (concretization) or extension (generalization) of the initial value, neutralization or enhancement of emphase, functional replacement, description (explication) or comment [10, p. 103].

According to the definition of T. A. Kazakova concretization or narrowing, the initial value is used in cases where the method of information arrangement of the original unit is lower than the way of arrangement of corresponding unit in the target language [4, p. 104].

Extension (generalization) of the original unit takes place in cases where the method of informational arrangement of the original unit is higher than the method of ordering it corresponding to the content of the unit in the target language.

The analysis of the peculiarities of the translation of compound terminological phrases in a certain context gives grounds to claim that such techniques of lexico-semantic transformations, such as concretization and generalization, take place to convey the exact meaning of the term [4, p. 105].

Explication is used in the case a phrase is composed of terms that have not been used yet in a particular field of science or technology in the target language and require interpretation. Explication (descriptive translation) is a lexical-grammatical transformation in which the lexical unit of the source language is replaced by a phrase that gives an explanation or definition of the unit [4, p. 185].

Explication is an extremely productive means of translation of computer terms as the rapid development of the field of information technology does not allow many terms in a timely manner find their equivalents and gain a foothold in the target language. Multicomponent terminological phrases, such as: processor-specific code (a program bound to a specific processor); non-mouse program (a program that does not support mouse operation); nucleus (kernel of operating system) are translated via explication yet.

The performance of explication when translated into Ukrainian is also explained by differences in the means of word and phrase formation. English, which is analytical in structure, is characterized by domination of multicomponent noun phrases that are not typical of Ukrainian. The inconsistencies in the translation of multicomponent phrases are often eliminated by calquing with a change in the sequence of the components of the phrase [8, p. 199]. 
Therefore, in order to have an adequate descriptive translation, it is necessary to have a good knowledge of the subject area of the translated text in order to disclose the meaning of the term properly.

Conclusions. The analysis of theoretical literature shows that when translating the termphrase, it is necessary to carry out a detailed semantic analysis of the individual elements, taking into account the content of the source text. It is important to establish in which semantic relations the components are with each other and with the main component of the term-phrase. The nature of these relationships determines the arrangement and content of the translation of the term.

Transliteration / transcription are mainly used for the translation of separate words, terms, and calquing and explication are used for translation of terminological phrases.

Having analyzed the peculiarities of the translation of compound terms in a particular context, it can be stated that such lexico-semantic transformations, such as concretization and generalization, are used to convey the exact meaning of the term. If a phrase is composed of terms that have not yet been used in a particular field of science or technology in the target language and need their own interpretation, then such lexical and grammatical transformation as explication is used. The advantage of calquing over explication is that explication requires more words to convey semantics, and in the case of calquing each element of a phrase in the source language corresponds to one element of the phrase in the target language, therefore, the principle of saving language is implemented.

Having analyzed the considerable amount of lexical material, we can conclude that the most common means of translating compound terms in the field of engineering and information technology is calquing. The high frequency of calquing is functionally and pragmatically justified, since in this case the lexical correspondence of the translated elements is preserved as much as possible.

\section{References}

1. Акуленко В. В. О «ложных друзьях переводчика» / В. В. Акуленко // Англорусский и русско-английский словарь «ложных друзей переводчика» / сост. В. В. Акуленко, С. Ю. Комиссарчик, Р.В.Погорелова, В. Л. Юхт. - Москва : Сов. энциклопедия, 1969. - С. 371-384 ; Akulenko V. V. O «lozhnykh druzyakh perevodchika» / V. V. Akulenko // Anglo-russkiy i russko-angliyskiy slovar «lozhnykh druzey perevodchika» / sost. V. V. Akulenko, S. Yu. Komissarchik, R. V. Pogorelova, V. L. Yukht. Moskva : Sov. entsiklopediya, 1969. - S. 371-384.

2. Вейзе А. А. Перевод технической литературы с английского на русский : учеб. пособ. / А. А. Вейзе, Н. Б. Киреев, Н. К. Мирончиков. - Минск : Издательство «Киреев», 1997. - 112 с. ; Veyze A. A. Perevod tekhnicheskoy literatury s angliyskogo na russkiy : ucheb. posob. / A. A. Veyze, N. B. Kireev, N. K. Mironchikov. - Minsk : Izdatelstvo «Kireev», 1997. - $112 \mathrm{~s}$.

3. Снікєєва С. М. Особливості перекладу комп'ютерних термінів на українську мову / Є. М. Снікєєва // Вісник Сумського державного університету. - 2001. - № 5 (26) : Серія : Філологічні науки. - С. 54-59; Yenikieieva Ye. M. Osoblyvosti perekladu kompiuternykh terminiv na ukrainsku movu / Ye. M. Yenikieieva // Visnyk Sumskoho derzhavnoho universytetu. - 2001. - № 5 (26) : Seriia : Filolohichni nauky. - S. 54-59.

4. Казакова Т. А. Теория перевода (лингвистические аспекты) / Т. А. Казакова. Санкт-Петербург : Союз, 2001. - 320 с.; Kazakova T. A. Teoriya perevoda (lingvisticheskie aspekty) / T. A. Kazakova. - Sankt-Peterburg : Soyuz, 2001. - 320 s.

5. Комиссаров В. Н. Теория перевода : (лингвистические аспекты) : учеб. / В. Н. Комиссаров. - Москва : Высшая школа, 1990. - 253 с. ; Komissarov V. N. Teoriya 
perevoda: (lingvisticheskie aspekty) : ucheb. / V. N. Komissarov. - Moskva: Vysshaya shkola, 1990. - $253 \mathrm{~s}$.

6. Кутузов А. Б. Пролегомены к денотативной модели перевода компьютерных терминов / А. Б. Кутузов, В. Д. Табанакова // Актуальные проблемы лингвистики и терминоведения : междунар. сб. науч. тр., посвящ. юбилею проф. З. И. Комаровой. Екатеринбург: Уральский государственный педагогический университет, 2007. C. 38-40; Kutuzov A. B. Prolegomeny k denotativnoy modeli perevoda kompyuternykh terminov / A. B. Kutuzov, V. D. Tabanakova // Aktualnye problemy lingvistiki i terminovedeniya : mezhdunar. sb. nauch. tr., posvyashch. yubileyu prof. Z. I. Komarovoy. Yekaterinburg : Uralskiy gosudarstvennyy pedagogicheskiy universitet, 2007. - S. 38-40.

7. Пумпянский А. Л. Введение в практику перевода научной и технической литературы на английский язик / А. Л. Пумпянский. - Москва : Наука, 1965. - 289 с. ; Pumpyanskiy A. L. Vvedenie v praktiku perevoda nauchnoy i tekhnicheskoy literatury na angliyskiy yazik / A. L. Pumpyanskiy. - Moskva : Nauka,1965. - 289 s.

8. Селіванова О. О. Сучасна лінгвістика: термінологічна енциклопедія / О. О. Селіванова. - Полтава : Довкілля-К, 2006. - 716 с. ; Selivanova О. O. Suchasna linhvistyka: terminolohichna entsyklopediia / O. O. Selivanova. - Poltava : Dovkillia-K, 2006. $-716 \mathrm{~s}$.

9. Скороходько Э. Ф. Вопросы перевода английской технической литературы : (перевод терминов) / Э. Ф. Скороходько. - 2-е изд., испр. и доп. - Киев : Издательство Киевского университета, 1963. - 92 с. ; Skorokhodko E. F. Voprosy perevoda angliyskoy tekhnicheskoy literatury : (perevod terminov) / E. F. Skorokhodko. - 2-e izd., ispr. i dop. Kiev : Izdatelstvo Kievskogo universiteta, 1963. - 92 s.

10. Федоров А. В. Основы общей теории перевода : (линвгист. проблемы) / А. В. Федоров. - 4-е изд., перераб. и доп. - Москва: Высш. шк., 1983. - 320 с. ; Fedorov A. V. Osnovy obshchey teorii perevoda : (linvgist. problemy) / A. V. Fedorov. - 4-e izd., pererab. i dop. - Moskva : Vyssh. shk., 1983. - 320 s.

11. Shalova N. Structural models of composite terms in the field of mechanical engineering and IT / N. Shalova, O.Zarivna // Вісник Маріупольського державного університету. Серія : Філологія. - 2018. - Вип. 19. - С. 367- 374 ; Shalova N. Structural models of composite terms in the field of mechanical engineering and IT / N. Shalova, O. Zarivna // Visnyk Mariupolskoho derzhavnoho universytetu. Seriia : Filolohiia. - 2018. Vyp. 19. - S. 367-374.

Submitted October $30^{\text {th }}, 2019$.

\section{Н. С. Шалова \\ O. T. Зарівна}

ЛЕКСИЧНІ ЗАСОБИ ТА ПРИЙОМИ ДОСЯГНЕННЯ ЕКВІВАЛЕНТНОСТІ ПЕРЕКЛАДУ СКЛАДЕНИХ ТЕРМІНІВ НА ОСНОВІ ПІДМОВ МАШИНОБУДУВАННЯ ТА ІНФОРМАЦЙНИХ ТЕХНОЛОГІЙ

Ця стаття присвячена дослідженню лексичних засобів та прийомів досягнення еквівалентності перекладу складених термінів на основі підмов машинобудування та інформаційних технологій. Питання даного дослідження є актуальним, оскільки лінгвісти зацікавлені в проблемі досягнення еквівалентності перекладу галузевих терміносистем, але з иієї точки зору вони ще не вивчені. Наукова новизна роботи визначається тим, щзо в ній здійснено комплексний аналіз особливостей досягнення еквівалентності при перекладі термінологічних словосполучень; з'ясовано характер засобів та прийомів перекладу складених термінів, визначено лексико-семантичні та лексико-граматичні прийоми перекладу складених термінів на основі підмов 
машинобудування та інформаційних технологій. Як показує аналіз теоретичної літератури при перекладі терміна-словосполучення необхідно провести докладний смисловий аналіз окремих елементів, враховуючи зміст тексту оригіналу. Проаналізувавши особливості перекладу складених термінів в певному контексті, можна стверджувати, що такі лексико-семантичні трансформації, як конкретизація та генералізачія, використовуються для передачі точного значення терміна. Якщо словосполучення складається з термінів, які ше не ввійшли до вжитку у певній галузі науки чи техніки мовою перекладу і потребують свого тлумачення, використовується така лексико-граматична трансформачія, як експлікація. Перевагою калькування над експлікацією є те, щуо експлікачія потребує більше слів для передачі семантики, a y випадку калькування кожному елементу словосполучення мовою оригіналу відповідає один елемент словосполучення мовою перекладу, отже, реалізується принции економії мовних засобів. Проаналізувавши значний обсяг лексичного матеріалу, можна дійти висновку, щьо найпоширенішим засобом перекладу складених термінів у галузі машинобудування та інформаційних технологій є калькування. Висока частотність калькування $\epsilon$ функціонально $i$ прагматично виправданою, оскільки y иьвому випадку максимально зберігається лексична відповідність елементів перекладу.Відповідно до важливості та актуальності даного дослідження ми розглядаємо подальший аналіз прийомів та методів перекладу термінологічних словосполучень підсистем машинобудування та інформачійних технологій з точки зору шляхів досягнення еквівалентності при перекладі на українську мову як перспективне дослідження.

Ключові слова: складені терміни, калькування, експлікаџія, мова оригіналу, мова перекладу, семантичні особливості.

УДК 811.111’373

\section{Shapa \\ E. Lebedieva \\ O. Gvozd}

\section{SUFFIX MORPHEMES IN THE ATTRIBUTES \\ OF TWO-COMPONENT ATTRIBUTIVE CONSTRUCTIONS AS STYLE DISTINCTIVE MARKERS OF OFFICIAL DISCOURSE}

The article presents the comparative analysis results of differential and integral characteristics of suffix morphemes in the attributes of two-component attributive constructions which was carried out with the goal to identify attributes with suffixes as stylistic markers of official discourse.

Key words: discourse, frequency of usage, amount, lexical meaning, suffix morpheme, genre, total frequency.

DOI 10.34079/2226-3055-2019-12-21-224-233

The definition of style distinctive markers in various types of discourses can be considered as one of the most important problems in discourse science. First it promotes more 